\title{
Effect of elemental sulphur on solubility of soil heavy metals and their uptake by maize
}

\author{
Yanshan Cui, Yiting Dong, Haifeng Li, Qingren Wang* \\ Research Centre for Eco-Environmental Sciences, Chinese Academy of Sciences, Beijing 100085, China
}

Received 29 March 2003; accepted 21 July 2003

\begin{abstract}
A pot experiment was conducted to study the influence of elemental sulphur $(\mathrm{S})$ on solubility of soil $\mathrm{Pb}, \mathrm{Zn}$ and $\mathrm{Cd}$ and uptake by maize

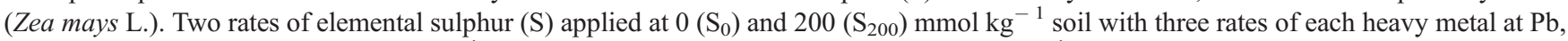
$0\left(\mathrm{~Pb}_{0}\right), 200\left(\mathrm{~Pb}_{200}\right), 400\left(\mathrm{~Pb}_{400}\right) \mathrm{mg} \mathrm{kg}{ }^{-1}$ soil, $\mathrm{Zn}, 0\left(\mathrm{Zn}_{0}\right), 100\left(\mathrm{Zn}_{100}\right), 200\left(\mathrm{Zn}_{200}\right) \mathrm{mg} \mathrm{kg}^{-1}$ soil and $\mathrm{Cd}, 0\left(\mathrm{Cd}_{0}\right), 50\left(\mathrm{Cd}_{50}\right), 100\left(\mathrm{Cd}_{100}\right)$ $\mathrm{mg} \mathrm{kg}^{-1}$ soil, respectively. The result showed that with $\mathrm{S}$ application at $200 \mathrm{mmol} \mathrm{S} \mathrm{kg}{ }^{-1}$, soil $\mathrm{pH}$ decreased about 0.3 unit and the solubility of the $\mathrm{Zn}$ and $\mathrm{Cd}$ was significantly increased, but the solubility of $\mathrm{Pb}$ had no significant influence. The concentration of $\mathrm{Pb}, \mathrm{Zn}$ and $\mathrm{Cd}$ in maize shoots and roots were increased with increasing rates of heavy metals. However, the concentration of $\mathrm{Zn}$ and $\mathrm{Cd}$ in shoots and roots were higher with application of $\mathrm{S}$ rather than without $\mathrm{S}$ but no significant difference was found for $\mathrm{Pb}$. The highest concentration of $\mathrm{Zn}$ in the shoots was 2.3 times higher with application of $\mathrm{S}$ rather than without at the same rate of $\mathrm{Zn}, 200 \mathrm{mg} \mathrm{kg}^{-1}$. Plant biomass was also significantly affected by the application of S and of heavy metals. With heavy metal addition, the shoot and root biomass were decreased with the rates of those of heavy metals increased either with or without application of S. However, the shoot biomass was significantly decreased with $\mathrm{S}$ application at the same rate of heavy metals except that with $\mathrm{Zn}$ addition. The removal of $\mathrm{Cd}$ and $\mathrm{Pb}$ by maize uptake and accumulation with application of $\mathrm{S}$ had no significant increase compared to that without, but the removal $\mathrm{Zn}$ by maize uptake from the soil increased by application of S, $90.9 \mu$ g plant $^{-1}$ contrast to $25.7 \mu \mathrm{g}$ plant ${ }^{-1}$ at $\mathrm{Zn}_{200}$ within a growth period of only 40 days.
\end{abstract}

(C) 2003 Elsevier Ltd. All rights reserved.

Keywords: Elemental sulphur; Solubility; Cd; Zn; Pb; Uptake; Maize

\section{Introduction}

Soil contamination by heavy metals is an important issue around the world because some metals are very toxic to microorganisms, plants and animals. With a rapid increase in industry and city population in most cities of China, soil contamination has also become an important concern around the country (Wang et al., 2001). There is considerable interest in the development of techniques for remediation of sites contaminated with heavy metals at minimal cost with the least environmental side effects.

In recent years, phytoremediation (especially phytoextraction) has been considered as a cost-effective approach to remediate soil contaminated by heavy metals. The success of phytoremediation depends on several factors, e.g., plant

\footnotetext{
* Corresponding author. Current address: TREC, IFAS, UFL, Homestead, FL 33031, USA. Tel.: +1-305-246-7001x280; fax: +1-305-246-7003

E-mail address: QRWANG@mail.ifas.ufl.edu (Q. Wang).
}

must produce sufficient biomass while accumulating a high concentration of the certain metal. The metal-accumulating plants also need to be responsive to agricultural practices to allow repeated planting and harvesting of the metal-rich tissues (Blaylock et al., 1997). Therefore, enhancing metal accumulation in existing high yielding crop plants without diminishing their yield is the most feasible strategy in the development of phytoremediation and maize is often used as a metal accumulator in phytoremediation experiments (Huang et al., 1997; Brennan and Shelley, 1999; Bricker et al., 2001).

In the process of phytoremediation, the bioavailability of heavy metals is an important factor. There are two main approaches that have been used to increase the bioavailability of heavy metals in soils and the mobility of heavy metals within plants: lowering soil pH (Salt et al., 1995; Chlopecka et al., 1996; Blaylock et al., 1997) and adding synthetic chelates (Blaylock et al., 1997) such as ethylenediaminetetraacetic acid (EDTA), nitrilotriacetic acid (NTA) and diethylenetriaminepentaacetic acid (DTPA). A decrease in soil 
$\mathrm{pH}$ can be achieved by application of mineral or organic acids or acid-producing fertilizers such as ammonium chloride (Salt et al., 1995; Huang et al., 1997; Wasay et al., 1998). However, these methods have some limitations due to negative effects on the chemical, physical and biological properties of the soil, or may lead to groundwater pollution through leaching. To avoid some of these constraints, the use of elemental $\mathrm{S}$ to decrease soil $\mathrm{pH}$ and increase the solubility of heavy metals in soils has been suggested (Tichý et al., 1997; Seidel et al., 1998; Kayser et al., 2000). However, more investigations are needed to evaluate the feasibility of this method as a tool for the enhancement of metal solubility and uptake by a metal accumulator, especially in alkaline or neutral soils contaminated by different concentrations of heavy metals. Therefore, the objectives of this study were to (1) compare the metal solubility of soil with different concentrations of $\mathrm{Pb}, \mathrm{Zn}$ and $\mathrm{Cd}$ addition by application of $S$ and (2) investigate the potential to increase metal uptake and accumulation by maize through application of $\mathrm{S}$.

\section{Materials and methods}

\subsection{Soil characteristics}

Soil (clay loam) was collected from the top $20 \mathrm{~cm}$ of the profile in Qinghe, Beijing, China. The physicochemical properties of the soil before the experiment were: $\mathrm{pH}$ 7.7 , organic mater content $22 \mathrm{~g} \mathrm{~kg}^{-1}$, total $\mathrm{Pb} 130 \mathrm{mg}$ $\mathrm{kg}^{-1}$, total $\mathrm{Zn} 120 \mathrm{mg} \mathrm{kg}^{-1}$, total $\mathrm{Cd} 0.05 \mathrm{mg} \mathrm{kg}^{-1}$, $\mathrm{CaCl}_{2}$-extractable $\mathrm{Pb} 0.45 \mathrm{mg} \mathrm{kg}^{-1}, \mathrm{CaCl}_{2}$-extractable $\mathrm{Zn}$ $0.98 \mathrm{mg} \mathrm{kg}^{-1}$.

\subsection{Plants and cultivation}

Maize (Zea mays L.) seeds were sown at a rate of 4 pot $^{-1}$ and thinned to leave two seedlings in each pot 1 week after germination. The experiment was carried out in a greenhouse with a $14 \mathrm{~h}\left(26{ }^{\circ} \mathrm{C}\right) / 10 \mathrm{~h}\left(13{ }^{\circ} \mathrm{C}\right)$ day/night cycle. Soil moisture content was adjusted regularly by weight to about $60 \%$ of water holding capacity and the plants were grown for 40 days.

\subsection{Experimental design and treatments}

The experimental designs were employed with elemental sulphur ( $\mathrm{S}$ ) and $\mathrm{Pb}, \mathrm{Zn}$ or $\mathrm{Cd}$. Sulphur was applied and mixed thoroughly with the soil at two rates, $0\left(\mathrm{~S}_{0}\right)$, and 200 $\left(\mathrm{S}_{200}\right) \mathrm{mmol} \mathrm{\textrm {kg } ^ { - 1 }}$ soil and three heavy metals applied with three rates, $\mathrm{Pb}$ at $0\left(\mathrm{~Pb}_{0}\right), 200\left(\mathrm{~Pb}_{200}\right), 400\left(\mathrm{~Pb}_{400}\right) \mathrm{mg} \mathrm{kg}^{-1}$ soil, $\mathrm{Zn}$ at $0\left(\mathrm{Zn}_{0}\right), 100\left(\mathrm{Zn}_{100}\right), 200\left(\mathrm{Zn}_{200}\right) \mathrm{mg} \mathrm{kg}^{-1}$ soil and $\mathrm{Cd}$ at $0\left(\mathrm{Cd}_{0}\right), 50\left(\mathrm{Cd}_{50}\right), 100\left(\mathrm{Cd}_{100}\right) \mathrm{mg} \mathrm{kg}^{-1}$ soil, respectively. There were 18 treatments in total and each one with three replicates. The individual metals were added by metal solutions $\left(\mathrm{Pb}\left(\mathrm{NO}_{3}\right)_{2}, \mathrm{Zn}\left(\mathrm{NO}_{3}\right)_{2}\right.$ or $\mathrm{Cd}\left(\mathrm{NO}_{3}\right)_{2}$ after $\mathrm{S}$ was added, the adding concentrations of the three metal solutions were $38.6,61.2$ and $17.8 \mathrm{mmol} \mathrm{l}^{-1}$, respectively. Fertilizer was applied at the rates of $120 \mathrm{mg} \mathrm{N}$ (as $\mathrm{NH}_{4} \mathrm{NO}_{3}$ ), $35 \mathrm{mg} \mathrm{P}$ (as $\mathrm{KH}_{2} \mathrm{PO}_{4}$ ) and $100 \mathrm{mg} \mathrm{K}$ (as $\mathrm{KCl}$ and $\left.\mathrm{KH}_{2} \mathrm{PO}_{4}\right) \mathrm{kg}^{-1}$ soil before seeding, which was about 12 days after metal contaminants were added in. Each pot received $1 \mathrm{~kg}$ of soil that was allowed to equilibrate for a period of 14 days after $\mathrm{S}$ was put in then the plant seeds were sown in the greenhouse.

\subsection{Sampling and analysis}

The soil samples were taken before and after the experiment, then air dried, ground and sieved passing through a $2-\mathrm{mm}$ sieve. Soil $\mathrm{pH}$ was measured with subsamples using a 1:2.5 (soil/0. $01 \mathrm{M} \mathrm{CaCl}_{2}$ ) ratio by a $\mathrm{pH}$ meter. For soil extractable metals, $20 \mathrm{ml}$ of $0.01 \mathrm{M} \mathrm{CaCl}_{2}$ were added to $2.00 \mathrm{~g}$ of air-dried soil in a 50-ml polypropylene centrifuge tube. The tube was shaken end-over-end for $16 \mathrm{~h}$ at $25^{\circ} \mathrm{C}$, centrifuged at $4000 \mathrm{rpm}$ for $10 \mathrm{~min}$. The supernatant was decanted and saved for $\mathrm{Pb}, \mathrm{Zn}$ and $\mathrm{Cd}$ determination by atomic absorption spectrophotometry (AAS: Z-6100 Hitachi, Japan) and inductively coupled plasma-optical emission spectroscopy (ICP-OES: Optima-2000, Perkin-Elmer, USA) in order to ensure the results are identical (Novozamsky et al., 1993; Degryse et al., 2003). For the total amount of metals, the air-dried soil was ground and sieved by passing through a $0.25-\mathrm{mm}$ sieve and the subsamples were digested with a mixture of concentrated $\mathrm{HNO}_{3} / \mathrm{HClO}_{4} / \mathrm{HF}(3: 1: 1)$ (the concentrations of $\mathrm{HNO}_{3}, \mathrm{HClO}_{4}$ and $\mathrm{HF}$ were 15.6, 11.7 and $19.7 \mathrm{~mol}^{-1}$, respectively) and then the total concentrations of $\mathrm{Pb}, \mathrm{Zn}$ and $\mathrm{Cd}$ were determined by AAS. After plant harvest, the soil samples were taken, air dried, ground and sieved by passing through a $2-\mathrm{mm}$ sieve. Soil $\mathrm{pH}, \mathrm{CaCl}_{2}$-extractable $\mathrm{Pb}, \mathrm{Zn}$ and $\mathrm{Cd}$ were also determined with the same methods as described above.

All the plants were harvested after the experiment and the plant samples were rinsed with deionized water, oven dried at $70{ }^{\circ} \mathrm{C}$ for $48 \mathrm{~h}$, ground with an agate mill, digested with a mixture of concentrated $\mathrm{HNO}_{3}: / \mathrm{HClO}_{4} / \mathrm{HF}$ (3:1:1 in volume), and analyzed by AAS. The data were subjected to ANOVA and subsequently to Duncan's multiple range test by application of SAS package (version 8.1, SAS, Cary, NC, USA).

\section{Results and discussion}

\subsection{Soil $p H$}

Soil $\mathrm{pH}$ decreased in all the treatments with application of S compared to the control (Table 1). One important fact is the oxidation of $\mathrm{S}$ by certain groups of acidophilic bacteria, notably Thiobacillus spp. in the soil (Lee et al., 1988; Seidel et al., 1998; Tichý et al., 1997; Kayser et al., 2000). Tichý et al. (1997) reported that $156 \mathrm{mmol}$ of different types of 
Table 1

Changes in soil $\mathrm{pH}$ under different treatments of heavy metals and $\mathrm{S}$ application after 14 and 54 days

\begin{tabular}{llllll}
\hline Treatment & \multicolumn{2}{l}{ 14 Days } & & \multicolumn{2}{l}{54 Days } \\
\cline { 2 - 3 } \cline { 5 - 6 } & $\mathrm{S}_{0}$ & $\mathrm{~S}_{200}$ & & $\mathrm{~S}_{0}$ & $\mathrm{~S}_{200}$ \\
\hline $\mathrm{Pb}_{0}$ & 7.69 & 7.53 & 7.49 & 7.26 \\
$\mathrm{~Pb}_{200}$ & 7.63 & 7.46 & 7.43 & 7.29 \\
$\mathrm{~Pb}_{400}$ & 7.63 & 7.42 & 7.40 & 7.27 \\
$\mathrm{Zn}_{0}$ & 7.69 & 7.53 & 7.49 & 7.26 \\
$\mathrm{Zn}_{100}$ & 7.60 & 7.48 & 7.46 & 7.26 \\
$\mathrm{Zn}_{200}$ & 7.63 & 7.37 & 7.46 & 7.23 \\
$\mathrm{Cd}_{0}$ & 7.69 & 7.53 & 7.49 & 7.26 \\
$\mathrm{Cd}_{50}$ & 7.63 & 7.47 & 7.49 & 7.32 \\
$\mathrm{Cd}_{100}$ & 7.62 & 7.46 & 7.49 & 7.30
\end{tabular}

Analysis of variance for elemental sulphur (S), metals, time (days (D)) and their interactions

\begin{tabular}{llllll}
\hline S Lead $(\mathrm{Pb})$, Day & \multicolumn{2}{l}{ S Zinc $(\mathrm{Zn})$, Day } & \multicolumn{2}{l}{ S Cadmium $(\mathrm{Cd})$, Day } \\
\hline S level $(\mathrm{S})$ & $P<0.001$ & S level $(\mathrm{S})$ & $P<0.001$ & $\mathrm{~S}$ level $(\mathrm{S})$ & $P<0.001$ \\
$\mathrm{~Pb}$ level & $P=0.01$ & Zn level & $P=0.003$ & Cd level & $\mathrm{NS}$ \\
$(\mathrm{Pb})$ & & $(\mathrm{Zn})$ & & $(\mathrm{Cd})$ & \\
Day $(\mathrm{D})$ & $P<0.001$ & Day (D) & $P<0.001$ & Day (D) & $P<0.001$ \\
$\mathrm{~S} * \mathrm{~Pb}$ & $\mathrm{NS}$ & $\mathrm{S} * \mathrm{Zn}$ & $\mathrm{NS}$ & $\mathrm{S} * \mathrm{Cd}$ & $\mathrm{NS}$ \\
$\mathrm{S} * \mathrm{D}$ & $\mathrm{NS}$ & $\mathrm{S} * \mathrm{D}$ & $\mathrm{NS}$ & $\mathrm{S} * \mathrm{D}$ & $\mathrm{NS}$ \\
$\mathrm{Pb} * \mathrm{D}$ & $\mathrm{NS}$ & $\mathrm{Zn} * \mathrm{D}$ & $\mathrm{NS}$ & $\mathrm{Cd} * \mathrm{D}$ & $P=0.007$ \\
$\mathrm{~S} * \mathrm{~Pb} * \mathrm{D}$ & $\mathrm{NS}$ & $\mathrm{S} * \mathrm{Zn} * \mathrm{D}$ & $\mathrm{NS}$ & $\mathrm{S} * \mathrm{Cd} * \mathrm{D}$ & $\mathrm{NS}$ \\
\hline
\end{tabular}

${ }^{a}$ NS stands for no significant difference.

elemental sulphur per kilogram of soil were added to a gleyic cambisol with an initial soil $\mathrm{pH}$ between 5 and 5.5, the soil $\mathrm{pH}$ decreased to 3.3 within 80 days. Kayser et al. (2000) reported that adding $36 \mathrm{~mol} \mathrm{~S} \mathrm{~m}^{-2}$ to the soil led to a decrease in soil $\mathrm{pH}$ from 7.2 to 6.9 . In the present experiment, adding $\mathrm{S}$ also acidified the soil, which caused the soil $\mathrm{pH}$ to decrease about 0.3 unit within 54 days.

\subsection{Soil extractable $\mathrm{Pb}, \mathrm{Zn}$ and $\mathrm{Cd}$}

As shown in Table 2, soil $\mathrm{CaCl}_{2}$-extractable $\mathrm{Pb}$ concentrations changed a little with or without $\mathrm{S}$ application, but the concentrations of $\mathrm{CaCl}_{2}$-extractable $\mathrm{Zn}$ and $\mathrm{Cd}$ markedly increased with soil $\mathrm{pH}$ decrease for all the treatments with $\mathrm{Zn}$ and $\mathrm{Cd}$ addition by application of $\mathrm{S}$. The highest concentration of $\mathrm{CaCl}_{2}$-extractable $\mathrm{Zn}$ was $2.28 \mathrm{mg} \mathrm{kg}^{-1}$ at the treatment of $\mathrm{Zn}_{200}$ associated with application of S, 1.8-fold higher than that with the same rate of $\mathrm{Zn}$ without application of $\mathrm{S}$. The highest concentration of $\mathrm{CaCl}_{2}$-extractable $\mathrm{Cd}$ was $2.07 \mathrm{mg} \mathrm{kg}^{-1}$ at the treatment of $\mathrm{Cd}_{100}$ with application of S, 9.9-fold higher than that with the same rate of $\mathrm{Cd}$ without application of $\mathrm{S}$.

The mobile fraction of soil heavy metals is greatly influenced by soil $\mathrm{pH}$ and generally increases as soil $\mathrm{pH}$ decreases (Kayser et al., 2000; Martínez and Motto, 2000). Kayser et al. (2000) used $\mathrm{NaNO}_{3}$ to extract metals from soil who found that $\mathrm{NaNO}_{3}$-extractable $\mathrm{Cd}$ and $\mathrm{Zn}$ increased 35and 8-fold, respectively, when soil $\mathrm{pH}$ reduced from 7.2 to 6.9. In our experiment, the $\mathrm{CaCl}_{2}$-extractable fractions of $\mathrm{Zn}$ and $\mathrm{Cd}$ increased 0.8 and 8.9 times, respectively, when 200 mmol S kg-1 was applied and when soil $\mathrm{pH}$ decreased about 0.3 unit with the treatments of $\mathrm{Zn}_{200}$ and $\mathrm{Cd}_{100}$. Reddy et al. (1995) found that at low pH, dissolved metal concentration in soil water extracts was dominated by free ionic forms (e.g. $\mathrm{Zn}^{2+}$ ) followed by ion pairs (e.g. $\mathrm{ZnSO}_{4}^{0}$ ). The availability and mobility of metal ions increased with the soil $\mathrm{pH}$ decreased due to these chemical forms increased in soil solutions. Since $\mathrm{Pb}$ is a relatively immobile metal in soils due to complexation with organic matter, sorption on oxides and clays, and precipitation as carbonates, hydroxides and phosphates, therefore the concentration of extractable $\mathrm{Pb}$ did not show any increase with a decrease in soil $\mathrm{pH}$.

\subsection{Shoot and root yield}

Plant dry matter biomass was also significantly affected by the application of $\mathrm{S}$ and heavy metals (Fig. 1). With heavy metal addition, the shoot and root biomass decreased when the concentration of heavy metals increased either with or without application of S. Compared to the control (without $\mathrm{S}$ application), the shoot biomass was significantly decreased with the $S$ application at the same rate of heavy metals except for the treatments with $\mathrm{Zn}$ addition. Regarding the root biomass, except for the control and the treatment with $\mathrm{Zn}$ addition, it was lower with $\mathrm{S}$ application than without. Kayser et al. (2000) reported that shoot weight in some plants did not change significantly with $\mathrm{S}$ application. However, in the present experiment, application of $\mathrm{S}$ decreased the weight of plant shoots except the treatment of $\mathrm{Zn}$ addition. One of the possibilities was that the soil $\mathrm{pH}$

Table 2

Soil $\mathrm{CaCl}_{2}$-extractable $\mathrm{Pb}, \mathrm{Zn}$ and $\mathrm{Cd}\left(\mathrm{mg} \mathrm{kg}^{-1}\right)$ after maize harvest

\begin{tabular}{lll}
\hline Treatment & $\mathrm{S}_{0}$ & $\mathrm{~S}_{200}$ \\
\hline $\mathrm{Pb}_{0}$ & $0.43(\mathrm{~Pb})^{\mathrm{a}}$ & $0.63(\mathrm{~Pb})$ \\
$\mathrm{Pb}_{200}$ & $0.80(\mathrm{~Pb})$ & $0.79(\mathrm{~Pb})$ \\
$\mathrm{Pb}_{400}$ & $0.81(\mathrm{~Pb})$ & $0.81(\mathrm{~Pb})$ \\
$\mathrm{Zn}_{0}$ & $0.99(\mathrm{Zn})$ & $1.24(\mathrm{Zn})$ \\
$\mathrm{Zn}_{100}$ & $1.05(\mathrm{Zn})$ & $1.75(\mathrm{Zn})$ \\
$\mathrm{Zn}_{200}$ & $1.26(\mathrm{Zn})$ & $2.28(\mathrm{Zn})$ \\
$\mathrm{Cd}_{0}$ & $\mathrm{BDL}$ & $\mathrm{BDL}$ \\
$\mathrm{Cd}_{50}$ & $0.13(\mathrm{Cd})$ & $0.86(\mathrm{Cd})$ \\
$\mathrm{Cd}_{100}$ & $0.21(\mathrm{Cd})$ & $2.09(\mathrm{Cd})$
\end{tabular}

Analysis of variance for elemental sulphur (S), metals and their interactions

\begin{tabular}{|c|c|c|c|c|c|}
\hline \multicolumn{2}{|c|}{ S Lead $(\mathrm{Pb})$} & \multicolumn{2}{|c|}{ S Zinc (Zn) } & \multicolumn{2}{|c|}{ S Cadmium $(\mathrm{Cd})$} \\
\hline $\begin{array}{l}\text { S level } \\
(\mathrm{S})\end{array}$ & $\mathrm{NS}^{\mathrm{c}}$ & $\begin{array}{l}\text { S level } \\
(\mathrm{S})\end{array}$ & $P=0.02$ & $\begin{array}{l}\text { S level } \\
\text { (S) }\end{array}$ & $P<0.001$ \\
\hline $\begin{array}{c}\mathrm{Pb} \text { level } \\
(\mathrm{Pb})\end{array}$ & $P=0.077$ & $\begin{array}{l}\text { Zn level } \\
(\mathrm{Zn})\end{array}$ & NS & $\begin{array}{l}\text { Cd level } \\
\text { (Cd) }\end{array}$ & $P<0.001$ \\
\hline $\mathrm{S} * \mathrm{~Pb}$ & NS & $\mathrm{S} * \mathrm{Zn}$ & NS & $\mathrm{S} * \mathrm{Cd}$ & $P<0.001$ \\
\hline
\end{tabular}

${ }^{a}$ Data showed the concentration of $\mathrm{CaCl}_{2}$-extractable metal that is in parenthesis.

${ }^{\mathrm{b}}$ Below detection limit.

${ }^{\mathrm{c}} \mathrm{NS}$ stands for no significant difference. 



Fig. 1. Shoot and root biomass of maize influenced by different treatments of heavy metals and $\mathrm{S}$ application: (a) shoot and (b) root. $\mathbf{8}-\mathrm{S}_{0}, \mathbf{\mathrm { O }}-\mathrm{S}_{200}$.

decreased, which may have introduced phytotoxicity by increasing the solubility and bioavailability of the heavy metals. The concentration of $\mathrm{Zn}$ addition did not reach the toxic concentration to the plant. However, another reason might be that different plants have different sensitivity to the toxicity of the metals or the amendment.

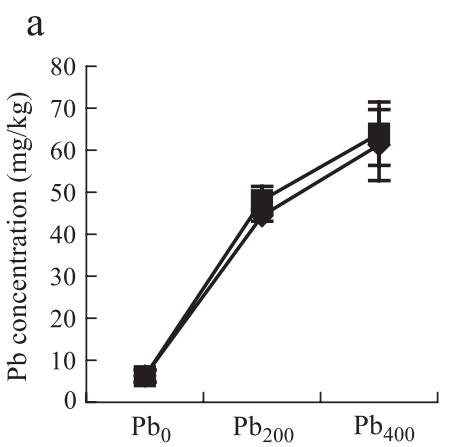

b

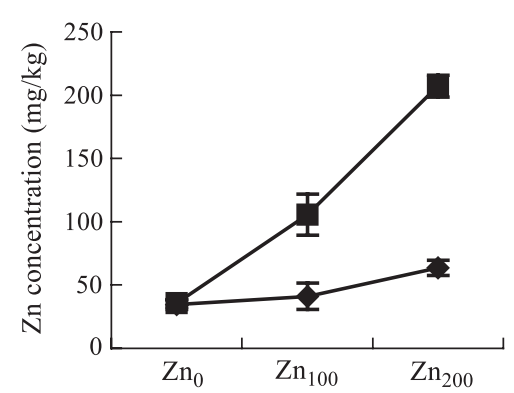

$\mathrm{c}$

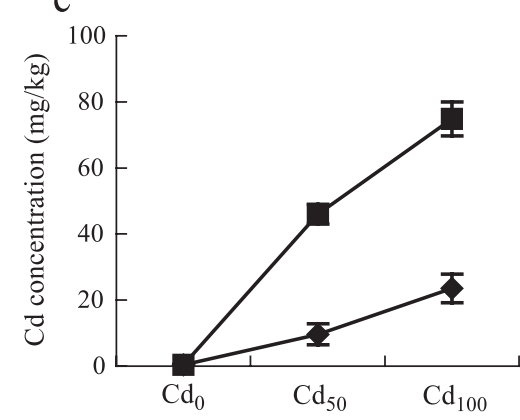

A

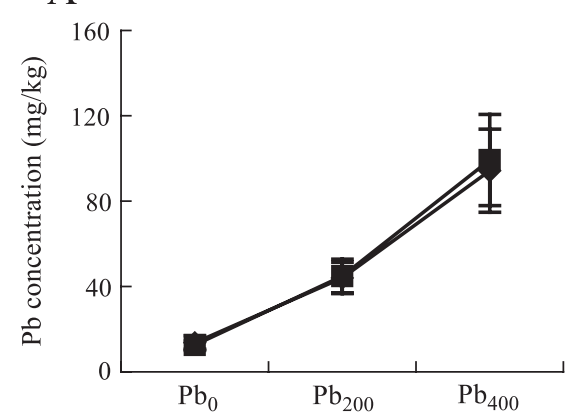

$\mathrm{B}$

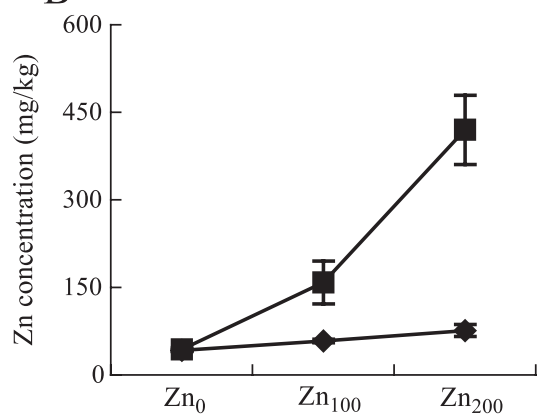

$\mathrm{C}$

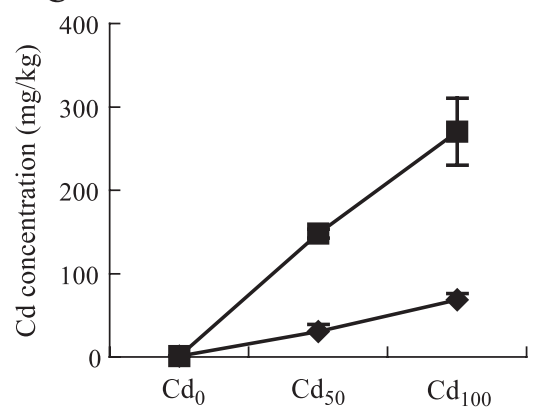

Fig. 2. The concentration (mean \pm S.E.*) of $\mathrm{Pb}, \mathrm{Zn}$ and $\mathrm{Cd}$ in shoots and roots of maize. (a) Shoot $\mathrm{Pb}$, (b) shoot $\mathrm{Zn}$ and (c) shoot $\mathrm{Cd}$. (A) Root $\mathrm{Pb}$, (B) root $\mathrm{Zn}$ and $(C)$ root Cd. $\triangleleft-S_{0}, \boldsymbol{\square}-S_{200}$. (*S.E. represents standard error of the means). 


\subsection{Accumulation of $\mathrm{Pb}$ and $\mathrm{Zn}$ in plant shoots and roots}

The concentrations of $\mathrm{Pb}, \mathrm{Zn}$ and $\mathrm{Cd}$ in shoots and roots increased with the increased application of heavy metals associated with S (Fig. 2). The concentrations of $\mathrm{Zn}$ and $\mathrm{Cd}$ in the shoots and roots were higher with application of $\mathrm{S}$ than without at the same rates of $\mathrm{Zn}$ and $\mathrm{Cd}$ addition (Fig. 2a and $\mathrm{A}, \mathrm{b}$ and $\mathrm{B}$ ), however, $\mathrm{Pb}$ concentration in the shoots and roots increased slightly with application of $\mathrm{S}$ compared to that without the same treatment of $\mathrm{Pb}$ (Fig. 2c and C).

It is well known that $\mathrm{Pb}$ is an immobile metal in soil since it readily forms a precipitate with a low aqueous solubility within the soil matrix, and in many cases it is not readily bioavailable, especially in alkaline or neutral soil (Blaylock et al., 1997; Martínez and Motto, 2000). In addition, many plants retain $\mathrm{Pb}$ in their roots via sorption and precipitation with only minimal transport to the aboveground harvestable plant portions (Kumar et al., 1995; Huang and Cunningham, 1996; Brennan and Shelley, 1999). In the present experiment, the increase of $\mathrm{Pb}$ concentration in maize shoots and roots is lower than that of $\mathrm{Zn}$ and $\mathrm{Cd}$.

Compared to without application of S, concentrations of $\mathrm{Zn}$ in maize roots and shoots increased by 4.5 and 2.3 times with application of $\mathrm{S}$ at the same treatment of $200 \mathrm{mg} \mathrm{Zn}$ $\mathrm{kg}^{-1}$ soil (Fig. $2 \mathrm{~b}$ and B). Concentrations of $\mathrm{Cd}$ in maize roots and shoots increased by 2.9 and 2.2 times with application of $\mathrm{S}$ at the same treatment of $100 \mathrm{mg} \mathrm{Cd}$ $\mathrm{kg}^{-1}$ soil (Fig. 2c and C). There are a number of reasons for this result in high plant uptake and accumulation of these heavy metals; however, the main reason is most probably that the increase of solubility of $\mathrm{Zn}$ and $\mathrm{Cd}$ leads to an improvement in metal bioavailability with a decrease of soil $\mathrm{pH}$ by application of $\mathrm{S}$. There are certain groups of acidophilic soil bacteria in the soil, predominantly the genus Thiobacillus, that can oxidize $\mathrm{S}$ and change it to $\mathrm{SO}_{4}^{2-}$ when soil pH has decreased (Lee et al., 1988; Tichý et al., 1997; Kayser et al., 2000). McLaughlin et al. (1998) reported that increasing $\mathrm{SO}_{4}^{2-}$ in soil could increase shoot $\mathrm{Cd}$ concentration, in the present experiment, the increasing $\mathrm{SO}_{4}^{2-}$ in soil (data were not given) may be another cause that increased the shoot $\mathrm{Cd}$ content.

\subsection{Removal of heavy metals}

Heavy metals removed by maize were shown in Table 3. It is well known that a good phytoextraction method depends on plants producing sufficient biomass while accumulating high concentrations of heavy metals. In the present experiment, the shoot $\mathrm{Zn}$ and $\mathrm{Cd}$ concentrations increased with the application $\mathrm{S}$ at the same treatment of $\mathrm{Zn}$ and $\mathrm{Cd}$ addition, but the shoot biomass of maize was significantly decreased by application of $\mathrm{S}$ and $\mathrm{Cd}$ due to the plant sensitivity to the toxicity of $\mathrm{Cd}$. Therefore, the removal of $\mathrm{Cd}$ with application of $\mathrm{S}$ had no significant impact compared to without $\mathrm{S}$ application. The increased
Table 3

Heavy metal content in the shoot of maize $\left(\mu \mathrm{g} \mathrm{plant}^{-1}\right)$

\begin{tabular}{lrr}
\hline Treatment & \multicolumn{1}{l}{$\mathrm{S}_{0}$} & \multicolumn{1}{l}{$\mathrm{S}_{200}$} \\
\hline $\mathrm{Pb}_{0}$ & $3.02(\mathrm{~Pb})^{\mathrm{a}}$ & $2.34(\mathrm{~Pb})$ \\
$\mathrm{Pb}_{200}$ & $18.52(\mathrm{~Pb})$ & $12.67(\mathrm{~Pb})$ \\
$\mathrm{Pb}_{400}$ & $22.40(\mathrm{~Pb})$ & $13.65(\mathrm{~Pb})$ \\
$\mathrm{Zn}_{0}$ & $17.16(\mathrm{Zn})$ & $11.64(\mathrm{Zn})$ \\
$\mathrm{Zn}_{100}$ & $16.31(\mathrm{Zn})$ & $46.92(\mathrm{Zn})$ \\
$\mathrm{Zn}_{200}$ & $25.73(\mathrm{Zn})$ & $90.89(\mathrm{Zn})$ \\
$\mathrm{Cd}_{0}$ & $0.24(\mathrm{Cd})$ & $0.18(\mathrm{Cd})$ \\
$\mathrm{Cd}_{50}$ & $3.12(\mathrm{Cd})$ & $3.73(\mathrm{Cd})$ \\
$\mathrm{Cd}_{100}$ & $5.87(\mathrm{Cd})$ & $5.66(\mathrm{Cd})$
\end{tabular}

Analysis of variance for elemental sulphur (S), metals and their interactions

\begin{tabular}{|c|c|c|c|c|c|}
\hline \multicolumn{2}{|c|}{ S Lead $(\mathrm{Pb})$} & \multicolumn{2}{|c|}{ S Zinc (Zn) } & \multicolumn{2}{|c|}{ S Cadmium $(\mathrm{Cd})$} \\
\hline $\begin{array}{l}\text { S level } \\
\text { (S) }\end{array}$ & $\mathrm{NS}^{\mathrm{b}}$ & $\begin{array}{l}\text { S level } \\
(\mathrm{S})\end{array}$ & $P=0.002$ & $\begin{array}{l}\text { S level } \\
\text { (S) }\end{array}$ & NS \\
\hline $\begin{array}{c}\mathrm{Pb} \text { level } \\
(\mathrm{Pb})\end{array}$ & $P<0.001$ & $\begin{array}{l}\text { Zn level } \\
(\mathrm{Zn})\end{array}$ & $P=0.002$ & $\begin{array}{l}\text { Cd level } \\
\text { (Cd) }\end{array}$ & $P<0.001$ \\
\hline $\mathrm{S} * \mathrm{~Pb}$ & NS & $\mathrm{S} * \mathrm{Zn}$ & $P=0.009$ & $\mathrm{~S} * \mathrm{Cd}$ & NS \\
\hline
\end{tabular}

${ }^{a}$ Data showed the content of metal that is in parenthesis.

${ }^{\mathrm{b}} \mathrm{NS}$ stands for no significant difference.

solubility of $\mathrm{Zn}$ had no negative effect on yield of maize but increased metal accumulation by maize directly translated into equivalent increases in metal removal. As for $\mathrm{Pb}$ removal, the decreased shoot biomass and $\mathrm{Pb}$ concentration in shoots of maize had no significant effects with the application of S. In fact, it is lower than without application of S (Table 3).

\section{Conclusions}

Soil $\mathrm{pH}$ decreased with $\mathrm{S}$ application and the solubility of the $\mathrm{Zn}$ and $\mathrm{Cd}$ was significantly increased in all treatments with $\mathrm{S}$ application. However, the solubility of $\mathrm{Pb}$ increased little by the treatment with S. Removal of $\mathrm{Zn}$ by maize was significantly increased with the application of $\mathrm{S}$ at the same rates of $\mathrm{Zn}$ addition, which implied that elemental sulphur can enhance uptake of $\mathrm{Zn}$ by maize. Removal of $\mathrm{Pb}$ and $\mathrm{Cd}$ did not significantly increase with the application of $\mathrm{S}$ for the same $\mathrm{Pb} / \mathrm{Cd}$-amended soil because maize was sensitive to the toxicity of $\mathrm{Pb} / \mathrm{Cd}$, which results in a severe loss of biomass production.

Although the application of $\mathrm{S}$ can increase uptake of some metals by plants by enhancing metal mobility, there is also a potential risk of movement of metals into the groundwater; with consequently environmental risk, an appropriate rate of $\mathrm{S}$ must therefore be considered in application in the field so that environmental risk can be minimized.

\section{Acknowledgements}

We thank the National Natural Science Foundation of China (Grant No. 40171087) and Chinese Academy of 
Sciences Knowledge Innovation Project (KZCX2-401-01) for their generous financial support to conduct the experiment.

\section{References}

Blaylock MJ, Salt DE, Dushenkov S, Zakharova O, Gussman C, Kapulnik $\mathrm{Y}$, et al. Enhanced accumulation of $\mathrm{Pb}$ in Indian mustard by soil-applied chelating agents. Environ Sci Technol 1997;31:860-5.

Brennan MA, Shelley ML. A model of the uptake, translocation, and accumulation of lead $(\mathrm{Pb})$ by maize for the purpose of phytoextraction. Ecol Eng 1999;12:271-97.

Bricker TJ, Pichtel J, Brown HJ, Simmons M. Phytoextraction of $\mathrm{Pb}$ and $\mathrm{Cd}$ from superfund soil: effects of amendments and croppings. J Environ Sci Health, A 2001;36:1597-610.

Chlopecka A, Bacon JR, Wilson MJ, Kay J. Forms of cadmium, lead, and zinc in contaminated soils from southwest Poland. J Environ Qual 1996;25:69-79.

Degryse F, Broos K, Smolders E, Merckx R. Soil solution concentration of $\mathrm{Cd}$ and $\mathrm{Zn}$ can be predicted with $\mathrm{CaCl}_{2}$ soil extract. Eur J Soil Sci 2003;54:149-57.

Huang JW, Cunningham S. Lead phytoextraction: species variation in lead uptake and translocation. New Phytol 1996;134:75-84.

Huang JW, Chen JJ, Berti WR, Cunningham SD. Phytoremediation of leadcontaminated soils: role of synthetic chelates in lead phytoextraction. Environ Sci Technol 1997;31:800-5.

Kayser A, Wenger K, Keller A, Attinger W, Felix HR, Gupta SK, et al. Enhancement of phytoextraction of $\mathrm{Zn}, \mathrm{Cd}$, and $\mathrm{Cu}$ from calcareous soil: the use of NTA and sulphur amendments. Environ Sci Technol 2000;34:1778-83.
Kumar PBAN, Dushenkov V, Motto H, Raskin I. Phytoextraction: the use of plants to remove heavy metals from soils. Environ Sci Technol 1995; 29:1232-8.

Lee A, Boswell CC, Watkinson JH. Effect of particle size on the oxidation of elemental sulphur, thiobacilli numbers, soil sulfate and its availability to pasture. NZ J Agric Res 1988;31:179-86.

Martínez CE, Motto HL. Solubility of lead and copper added to mineral soils. Environ Pollut 2000;107:153-8.

McLaughlin MG, Lambrechts RM, Smolders E, Smart MK. Effects of sulfate on cadmium uptake by Swiss chard: II. Effects due to sulfate addition to soil. Plant Soil 1998;202:217-22.

Novozamsky I, Lexmond THM, Houba VJG. A single extraction procedure of soil for evaluation of uptake of some heavy metals by plant. Int J Environ Anal Chem 1993;51:47-58.

Reddy KJ, Wang L, Gloss SP. Solubility and mobility of copper, zinc and lead in acidic environments. Plant Soil 1995;171:53-8.

Salt DE, Blaylock MJ, Kumar NPBA, Dushenkov V, Ensley BD, Chet I, et al. A novel strategy for removal of toxic metals from the environment using plants. Biotechnology 1995;13:468-74.

Seidel H, Ondruschka J, Morgenstern P, Stottmeister U. Bioleaching of heavy metals from contaminated aquatic sediments using indigenous sulphur-oxidizing bacteria: a feasibility study. Water Sci Technol 1998; 37:387-94.

Tichý R, Fajtl J, Kuzel S, Kolar L. Use of elemental sulphur to enhance a cadmium solubilization and its vegetative removal from contaminated soil. Nutr Cycl Agroecosyst 1997;46:249-55.

Wang QR, Dong Y, Cui Y, Liu X. Instances of soil and crop heavy metal contamination in China. Soil Sediment Contam 2001;10:497-510.

Wasay SA, Barrington SF, Tokunaga S. Remediation of soils polluted by heavy metals using salts of organic acids and chelating agents. Environ Technol 1998;19:369-79. 